\title{
Sexual Selection for Song Complexity and Modifications of Brain Structures in Songbirds
}

\author{
Kazuo OKanoya* \\ Faculty of Letters, Chiba University 1-33 Yayoi-cho, Inage-ku, 263-8522, Japan and \\ PRESTO, Japan Science and Technology Corporation, Kawaguchi, Saitama 332-0012, Japan
}

\begin{abstract}
The present review discusses whether sexual selection for complex songs modified brain structures in songbirds. If producing complex song is costly in males, song complexity should be correlated with some indexes of brain structures. At the same time, if selecting a potent mate based on song is costly in females, they also should develop some brain specializations correlated with the cognitive effort. Most existing studies focused on the volume of song control nuclei and song behavior. There are two main pathways for song control in the songbird brain: the posterior pathway that directly controls song production and the anterior pathway related with song perception. For the posterior pathway, between-species comparisons found positive correlations between the volume and behavior in males. However, most within-species comparisons failed to find such correlations. Several studies examined the relationship between song perception and the anterior pathway and lesion studies showed reduced selectivity for song in both males and females. Song selectivity and the volume of anterior pathway were positively correlated in females. Taken together, data are equivocal for the production part, but more consistent for the perception part. To study further the relationship between brain evolution and sexual selection in birdsong, methods for measuring song complexity need to be refined and other anatomical indexes besides volumetric methods should be examined.
\end{abstract}

Key Words: Female choice, Handicap principle, Honest signals, Sexual selection, Song control nuclei, Telencephalon.

Birdsong is generally regarded to have two major functions: territorial defense and mate attraction (Catchpole \& Slater 1995). In species that mainly use songs for the later purpose, songs should have evolved thorough the process of heterosexual selection (Darwin 1871), especially by the process of female choice. Several excellent reviews are already available in the topic of sexual selection and female choice in birdsong (e.g., Catchpole \& Slater 1995, Searcy \& Yasukawa 1996). We therefore focus on rather restricted issues in this review. We specially ask whether female choice affected brain structures. Are there brain structures that correlate with song complexity in males? Are there brain structures that correlate with song selection in females?

If songs are in fact sexually selected traits, production of songs should be costly in several ways. In that regard, songs should be "honest signals." One of such costs includes brain spaces used for song control. We should be able to show more brain spaces are devoted for the production of higher quality songs. Similarly, we should also be able to find that more brain spaces are 

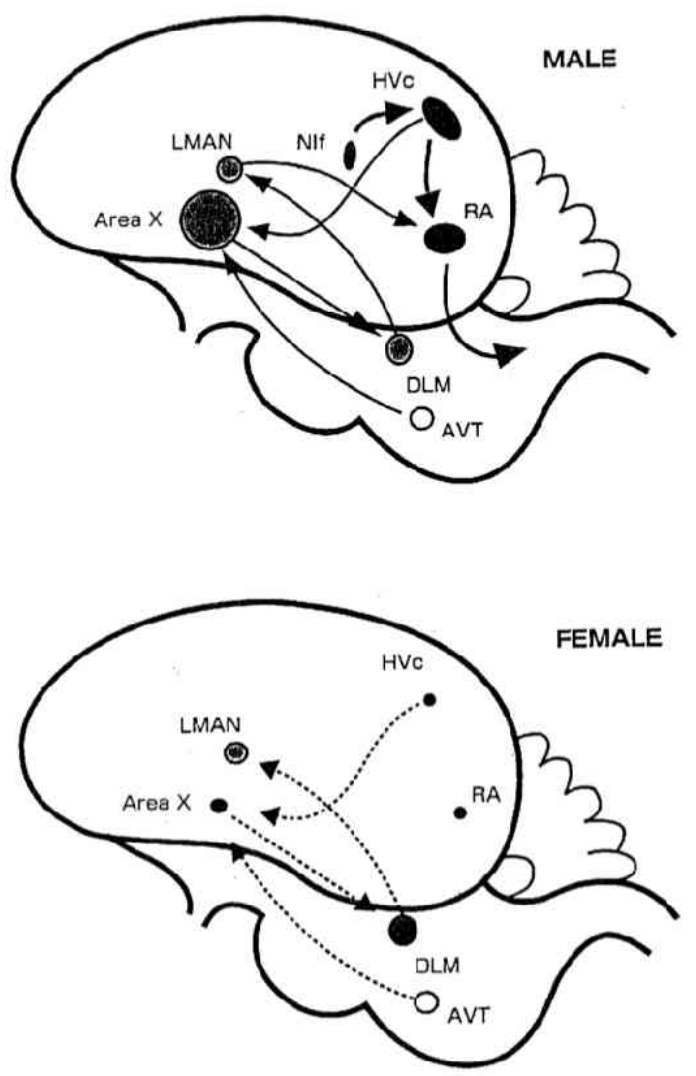

Fig. 1. Simplified diagrams showing songrelated brain circuit in the male (upper) and in the female (lower). Nuclei that are indicated by black circles (NIf, HVc, RA) are parts of the posterior pathway. Nuclei indicated by gray circles (LMAN, Area X, DLM) are that of the anterior pathway.

needed to make accurate judgment of the singer's potency based on song properties. These are the hypotheses we examined in this review.

Song control circuit in passerine birds is well identified (Fig. 1). Real time song production is controlled by the posterior pathway (Nottebohm et al. 1976). Bilateral lesion of nucleus HVc or RA resulted in degraded songs in all the species studied to date (e.g., Scharff \& Nottebohm 1991, Okanoya 1997). On the other hand, lesioning a nucleus in the anterior pathway (LMAN) did not result in real time degradation in adult song, but resulted in severely deteriorated song when lesioned as young (Bottjer et al. 1984).

The volumes of song control nuclei in the posterior pathway are sexually dimorphic (reviewed in MacDougall-Shackelton \& Ball 1999) and the degree of sexual dimorphism is, in general, correlated with the sexual dimorphism in song behavior (but see Gahr et al. 1998). On the other hand, few studies compared the volume of song control nuclei in the anterior pathway in males and females. In general, area $X$ is totally absent but LMAN could be identified in female birds (Bengalese finches Lonchura striata; Okanoya 1997, Cowbirds Molothrus ater, Hamilton et al. 1997). In fact, the volume of LMAN was not sexually dimorphic in these studies (Okanoya 1997, Hamilton et al. 1998). Metabolic activity as measured by cytochrome oxydase histochemistry (Okanoya 1997) also resulted in no sex differences in this nucleus.

These results produced an idea that the anterior pathway may be related with song perception rather than song production. Such idea, in turn, also reinforced the dogma that the posterior pathway is mainly for song production. In the following sections, we examined the relationships between song complexity, song selectivity, and both of the brain pathways in male and female songbirds.

\section{THE POSTERIOR PATHWAY}

\section{1) Song production in males}

Between-species comparisons resulted in positive findings. We asked: do the species that have more song repertoire possess larger brain nuclei than others? DeVoogd et al. (1993) examined the relationship between the relative volume of $\mathrm{HVc}$ to overall brain volume and song repertoire size in 41 
songbird species and found a significant correlation. In their study, song repertoire size was taken from literature. Definition of "repertoire size" might thus not be the same among species used. Overcoming such problems by using closely related species of eight European warblers, Szekely et al. (1996) found the syllable repertoire size of warblers was positively correlated with the residual volume of $\mathrm{HVc}$, but not with the residual volume of RA.

However, several within-species comparisons to date have not found significant relationships. For example, MacDougall-Shackelton et al. (1998a) studied correlation between song behavior and brain structures in male zebra finches Taeniopygia guttata. Volumes of the four major song control nuclei (HVc, RA, IMAN, and Area X) were measured and correlated with song behavioral measures such as number of elements, song rate in 30 min., and song durations. None of song measures was correlated with $\mathrm{HVc}$ or RA volumes. Furthermore, in a dueting species, Gahr et al. (1998) found rather negative results. Although males had a $\mathrm{HVC}$ volume twice as large as that of females, quantitative measures of the song complexity were identical between them.

These results suggest that volumetric studies may be very difficult when dealing with small individual differences. In the study by Szekely et al. (1996) the eight species of warblers differed in the repertoire size as much as 1 to 100 . On the other hand, the study by MacDougall-Shackelton et al. (1998a) used sixteen zebra finches whose repertoire size (actually, element types) ranged from 2 to 7 . Thus, in order to show volumetric correlation between $\mathrm{HVc}$ and song complexity, we need to find a species that has sufficiently large (around 100 fold) individual differences in song complexity.

2) Song perception in females
In many temperate species of songbirds, only males sing. In females of these species, the posterior pathway is either very small or totally missing. In some species of songbirds including the canary Serinus canarius, however, females sometimes develop rudiment of songs. Brenowitz (1991) showed that lesions placed in HVC of female canaries disrupt conspecific song selectivity measured by the copulation solicitation display (CSD) assay.

A similar experiment was conducted by MacDougall-Shackelton et al. (1998b) but results were quite different. They examined song selectivity in female zebra finches with the CSD assay. In this species, the anterior pathway in females is much smaller. When HVc was lesioned, no effect was observed. But when the caudal part of the hyperstriatum ventrale $(\mathrm{cHv})$ was lesioned, the birds lost selectivity.

\section{THE ANTERIOR PATHWAY}

\section{1) Song production in males}

Few studies focused on the anterior pathway and song production. The work by MacDougall-Shackelton et al. (1998a) mentioned previously also measured volumes of LMAN and Area X. In his study, the only significant correlation found was between the LMAN volume and the number of elements, but the correlation between them was negative. Thus, the more IMAN volume the bird had, the fewer song elements he sang.

Although not directly related with song complexity measures, Hamilton et al. (1998) found a negative correlation between the volume of Area X and song rates and song potency in brown-headed cowbirds. Song potency here was an average number of courtship displays emitted by females to each song. Thus, in this study, a male bird with smaller Area $\mathrm{X}$ was singing a song that 
could stimulate females more effectively.

Several other studies, however, did not find such correlations. In the study by Szekely et al. (1996) mentioned above, they did not find a significant correlation between the nucleus volume of the anterior forebrain pathway and syllable repertoire size in eight species of closely related warblers.

2) Song discrimination in males and song selection in females

In male zebra finches, lesioning Area $\mathrm{X}$ (Scharff et al. 1998) resulted in impaired discrimination performance of conspecific songs when measured by operant conditioning techniques. Similar techniques were applied to measure effects of LMAN lesion in female canaries (Burt et al. 1998) and resulted in impaired discrimination performances.

Among warbler species, LMAN volume of females positively correlated with syllable repertoire size of the conspecific males (DeVoogd et al. 1996). Within species comparison was done by Hamilton et al. (1997) who used the CSD score to measure song potency of conspecific songs in female brown-headed cowbird. In this species, only males sing and females never do. Females that discriminated more between the low potency song and the high potency song had larger LMAN volume. Based on their data, Hamilton et al. discussed the data by Brenowitz (1991) in which he lesioned HVc of female canaries and showed the loss of song selectivity might in fact be the side effect of eliminating auditory input to LMAN. Auditory information flows from Field L, the primary auditory cortex in birds, to HVc, Area X, DLM, and LMAN in this order.

\section{OTHER STRUCTURES THAT MIGHT BE INVOLVED}

1) Higher auditory area

Outside the song control nuclei in the caudal-medial neostriatum (NCM), an expression of immediate early gene, zenk occurs in the brain of songbirds when the individual is stimulated by the playback of conspecific songs (Mello et al. 1992). Immediate early genes are expressed when novel events that require neural modifications occur. When the same song was played several times, the expression of zenk decreased, but when another song was played, that resumed in the brain of male zebra finches (Mello et al. 1995). This phenomenon could be used as a marker of neural events in the songbird brain. Further studies confirmed that the gene expression occurs both in males and in females.

In the $\mathrm{NCM}$, neurons that responded to the playback of conspecific songs were found both in females and males (Chew et al. 1996). In both sexes these neurons stopped responding after several presentations of the same song but resumed responding when the reversal of the same song was played (Chew et al. 1996).

In female European starlings Sturnus vulgaris, zenk expression was correlated with stimulus song bout length (Gentner et al. 1998). When stimulated with longer song bouts of a male starling, NCM in females expressed more ZENK protein (protein synthesized by zenk gene) than when stimulated with shorter song bouts. Thus the NCM may also be a target region to study brain correlates of song selectivity in females.

\section{2) Hypothalamus}

Cheng et al. (1998) found in a region of the hypothalamus of female ring doves Streptopelia risoria, female-nest-coo-specific units which respond to the temporal 
organization of the two-note coo calls. This work suggested that feature detection for species-specific calls might also occur in the hypothalamus. If this was true for songbirds as well, song selectivity as measured by the CSD assay might not require processing in the telencephalon. Although no data equivalent to this have been reported in the song. bird brain, we need to reserve the possibility that some judgment on the song quality could also be done by extratelencephalic areas.

\section{CONCLUSION}

1) Perspectives in the study of female song perception

When perception is concerned, only one published report (Hamilton et al. 1997) is available and that showed within-species correlation between song selectivity and a nucleus volume in females of the brownheaded cowbird. Apparently, more studies with different species of birds are necessary to establish that the selection itself is a cost for females.

It is interesting to note, as long as the anterior pathway is concernsed, that data on males showed negative correlations between song complexity and volume of the nuclei, but the data on females showed positive correlation between song selection scores and volumetric results. At a glance, these data look quite contradictory. Operant conditioning results support the veiw that the anterior pathway might be important in making perceptual discriminations in males too. How would all of this information be put together? Obviously, these are questions to be addressed in future studies.

\section{2) Problems with correlative studies}

Between species comparisons showed that when song production is concerned, song complexity might require more brain spaces (DeVoogd et al. 1993, Szekely et al. 1996).
However, to show that song production is in fact a sexually selected trait, we do need to show a correlation between the volume of a song control nucleus and song complexity within single species. This has been difficult because of a lower range of individual variations of song complexity and higher degree of uncertainty associated with the processing the brain tissue.

Two problems are obvious. First, we need to increase accuracy of volumetric measurements. Since HVc is located on the dorsal edge of the telencephalon, making accurate sections without deforming is very difficult. Embedding procedures and slicing procedures might need more refinement. One possibility is to process the brain without removing it from the skull. Of course, the volumetric measurement is not the only index for the brain cost. Metabolic requirement of the specific region relative to others would also be an index of interest.

The definition of "song complexity" is also confusing. In a majority of the studies, song complexity simply referred to the number of identifiable song units (elements, syllables, motives, repertoires). However, songs could also be different in the ordering of the units. For example, when we compared the number of song elements in Bengalese finches (Lonchura striata var. domestica) and their wild strain, white-backed munias (Lonchura striata), we found no difference between the two, but the way the song elements were ordered differed (Honda \& Okanoya 1999). In this way, a song can be more "complex" than the other even if they have the same number of elements. Such parameters should also be considered when assessing song complexity. However, caution should be paid to examine whether females of the species are paying attention to such parameters.

This research was supported by PRESTO, JST. I thank Drs. S. Hamao, T. Oba, and E. Morton for 
the stimulating discussion we had during the course of preparing for the symposium.

\section{LITERATURE CITED}

Bottjer, S. W., Miesner, E. A. \& Arnold , A. P. 1984. Forebrain lesions disrupt development but not maintenance of song in passerine birds. Science 224: 901-902.

Brenowitz, E. 1991. Altered perception of speciesspecific song by female birds after lesions of a forebrain nucleus. Science 251: 303-305.

Burt, J. M., Brenowitz, E. A., Beecher, M. D. \& Lent, K. L. 1998. Behavioral evidence for the function of avian song nucleus IMAN. The Fifth Int. Cong. Neuroethol. pp 304.

Catchpole, C. K. \& Slater, P. J. B. 1995. Bird Song: biological themes and variations. Cambridge University Press, Cambridge.

Cheng, M., Peng, J. P. \& Johnson, P. 1998. Hypothalamic neurons preferentially respond to female nest coo stimulation: demonstration of direct acoustic stimulation of luteinizing hormone release. J. Neurosci. 18: 5477-5489.

Chew, S. J., Vicario, D. S. \& Nottebohm, F. 1996. A large-capacity memory system that recognizes the calls and songs of individual birds. Proc. Nat. Acad. Sci. USA 93: 1950-1955.

Darwin, C. 1871. The descent of the man and selection in relation to sex. London, John Murray.

DeVoogd, T. J., Krebs, J. R., Hearly, S. D. \& Purvis, A. 1993. Relationship between song repertoire size and the volume of brain nuclei related to song: comparative evolutionary analyses amongst oscine birds. Proc. R. Soc. Lond. B 254: $75-82$.

DeVoogd, T. J., Cardin, J. A., Szekely, T., Buhi, J. \& Newman, S. W. 1996. Relative volume of LMAN in female warblers species varies with number of songs produced by conspecific males. Soc. Neurosci. Abst. 22, 1401.

Gahr, M., Sonnenschein, E. \& Wickler, W. 1998. Sex differences in the size of the neural song control regions in a dueting songbird with similar song repertoire size of males and females. J. Neurosci. 18: 1124-1131.

Gentner, T. Q., Duffy, D. L., Kaloudis, P., Ellis, E. \& Ball, G. F. 1998. Behaviorally relevant variation in male song induces differential expression of the IEG zenk in a sub-region of NCM in females starlings. Soc. Neurosci. Abstr. pp 24.

Hamilton, K. S., King, A. P., Sengelaub, D. R. \& West, M. J. 1998. Visual and song nuclei correlate with courtship skills in brown-headed cowbirds. Anim. Behav. 56: 973-982.

Hamilton, K. S., King, A. P., Sengelaub, D. R. \& West, M. J. 1997. A brain of her own: a neural correlate of song assessment in a female songbird. Neurobiol. Learn. Mem. 68: 325-332.

Honda, E. \& Okanoya, K. 1999. Acoustical and syntactical comparisons between songs of the white-backed munia (Lonchura striata) and its domesticated strain, the Bengalese finch (Lonchura striata var. domestica). Zool. Sci. 16: 319-326.

MacDougall-Shackleton, S. A. \& Ball, G. F. 1999. Comparative studies of sex differences in the song-control system of songbirds. Trends. Neurosci. 22: 432-436.

MacDougall-Shackleton, S. A., Hulse, S. H. \& Ball, G. F. 1998a. Neural correlates of singing behavior in male zebra Finches (Taeniopygia guttata). J Neurobiol. 36: 421-430.

MacDougall-Shackleton, S. A., Hulse, S. H \& Ball, G. F. 1998b. Neural bases of song preferences in female zebra finches (Taeniopygia guttata). Neuroreport. 9: 3047-3052.

Mello, C. V., Vicario, D. S., \& Clayton, D. F. 1992. Song presentation induces gene expression in the songbird forebrain. Proc. Nat. Acad. Sci., USA 89: 6818-6877.

Mello, C, Nottebohm, F. \& Clayton, D. 1995. Repeated exposure to one song leads to a rapid and persistent decline in an immediate early gene's response to that Song in zebra finch telencephalon. J. Neurosci. 15: 69196925.

Nottebohm, F., Stokes, T. M., \& Leonard, C. M. 1976. Central control of song in the canary (Serinus canarius). J. Comp. Neurol. 165: 457 486.

Okanoya, K. 1997. Voco-auditory behavior in the Bengalese finch: a comparison with the zebra finch. Biomed. Res. 18: 53-70.

Scharff, C. \& Nottebohm, F. 1991. A comparative study of the behavioral deficits following lesions of various parts of the zebra finch song system: Implications for vocal learning. J. Neurosci. 11: 896-2913. 
Scharff, C., Nottebohm, F. \& Cynx, J. 1998. Conspecific and heterospecific song discrimination in male zebra finches with lesions in the anterior forebrain pathway. J. Neurobiol. 36: 81-90.

Searcy, W. A. \& Yasukawa, K. 1996. Song and female choice. In: D. E. Kroodsma \& E. H. Miller (eds.). Ecology and evolution of acoustic communication in birds. Ithaca, Cornell University Press.

Szekely, T., Catchpole, C. K., Devoogd, A., Marchl, Z. \& Devoogd, T. J. 1996. Evolutionary changes in a song control area of the brain (HVC) are associated with evolutionary changes in song repertoire among European warblers (Sylviidae). Proc. R. Soc. Lond. B 263: $607-610$.

(Received 17 January 2000 ; Accepted 25 August 2000) 


\title{
鳴禽類における歌の複雑さの性淘汰と脳構造の変化
}

(Sexual Selection for Song Complexity and Modifications of Brain Structures in Songbirds. 49: 79-85)

\author{
岡ノ谷一夫
}

千葉大学および科学技術振興事業団 $=263-8522$ 千葉市稲毛区弥生町1-33

一般に，鳥の歌にはなわばりの防衛とつがい相手の 誘引の 2 つの機能がある. 後者の機能に重点をおいて 歌をつかう種においては, 歌は異性間淘汰により進化 してきたと考えられる.このレビューでは, 複雑な歌 の性淘汰が鳥の脳の構造を変化させたかどうかを検討 する. 複雑な歌をうたうには，それを可能にする脳の コストがあるはずである. また，複雑な歌をきいてそ れにあとづきつがい相手を選択するのにも，選択に要 する認知機能が脳のコストとして存在するはずである. 頭蓋の容量は成熟後は変化しないから, 脳のコストは 端的に頭蓋内でどのくらい容量を占めるかで比較でき るであろう. したがって, 歌に関わる特定の機能に特 化した脳部位の体積を測定した研究を検討してみよう。

鳴禽類における歌制御回路は図 1 のとおりである. 歌の実時間産出は直接制御系と呼ばれる回路（神経核 HVc, RA）で行われる，一方，迂回投射系と呼ばれる 回路（神経核 Area X, DLM, LMAN) は歌の学習 と知覚に関連するとされている.

直接制御系の神経核の体積には性的 2 型があり, 歌 行動の性的 2 型と対応しているが, 迂回投射系ではそ のような対応は見られない，Area X はメスでは全く 同定できないが，LMAN はメスでもオスと同じくらい の体積をむつ.これらのデータから, 迁回投射系は歌 の学習と知覚に, 直接制御系は歌の実時間制御に関係 すると仮定されている.

直接制御系 : 直接制御系の神経核の体積は種レベルで みれば歌の複雑さと関係するが, 同一種内では関係は 明白ではなく, むしろ全く関係がないことを示したデー 夕もある. 種間比較では, 歌の複雑さの指標も100倍か らの違いが得られるが, 同一種内の比較ではせいぜい 4 倍程度である.おうらくこれが, 種内比較で肯定的 な結果が出ない理由であろう。

メスの歌選択性は, 歌のプレイバックに対してどの くらい交尾誘発姿勢 (CSD) が誘発されるかを指標之 することが多い，カナリアでは, HVc の破壊により CSD の選択性がなくなったという報告があるが，キン カチョウでは HVc の破壊による影響はなかった。これ
が種差と考えられるべきかどうかは不明である.

迁回投射系: 歌の複雑性と迂回投射系の関係を研究し た報告は少ない，キンカチョウでは, LMAN の体積と 歌の複雑さが逆相関したという報告がある。 また、コ ウウチョウでは AreaX の体積と歌の誘引力が逆相関し たことを示す研究がある. 歌の誘引力と複雑さの関係 については不明である. 一方，そのような関係は全く ないという報告あある.

キンカチョウでは, オスの AreaX を破壊することで, オペラント条件付けにより測定された歌の識別能力が 低下した。 また，同様な研究で，カナリアのメスの LMAN を破壊すると歌の識別に影響があるという。ム シクイに属する種では, メスの LMAN の体積がその種 のオスの歌の複雑さに関係するらしい，コウウチョウ では LMAN の体積とメスが選り好みする程度が相関し た.

その他の脳構造 : 伝統的に考えられている歌制御系と はまったく別の部位であるが，NCM と呼ばれる部位で は新奇な歌を聴くことで遺伝子発現が見られる.この 部位の神経細胞屯, 新奇な歌にのみ反応することがわ かっている. メスのホシムクドリでは，オスの歌の長 さに応じて NCM の異なる部分で遺伝子発現が見られ たと報告されている.

ハトでは, 視床下部の神経細胞がメスの特定の鳴き 声に反応する. あし鳴禽でも同様な細胞が発見されれ ば, 歌を分析するのは何す大脳だけではないというこ とになろう。

結論 : メスの歌知覚と脳構造の研究はデータそのもの がほとんどない.しかし，これはたいへん重要な分野 であり, 今後の展開が期待される. メスの歌知覚には 迁回投射系が関わっていることは間違いないであろう. オスもメスも迂回投射系の破壊により歌の弁別力が下 がるという報告は一致しているが，メスはLMAN が大 きい方が選択性が高く，オスは LMAN が小さいほうが 誘引効果の高い歌をうたう。こうした一見矛盾したデー 夕から LMAN の働きを洞察することが可能ではないだ ろうか. 
歌の複雑さと脳構造の関係は, 種間比較では検出で きるが, 同一種内の個体比較では検出されていない. しかし，性淘汰により歌と脳が変化したことを示すた めには, 同一種内のデータがぜひとも欲しいところで ある. 問題は脳にかかるコストを定量するための解剖 学の技術と, 歌の複雑さをどう定義するかにある。こ
れからの研究では，脳の体積をはかるだけではなく， 神経細胞の活性の度合い屯定量化するような方法が必 要である. また, 歌の「複雑さ」とはいえ, 要素の夕 イプ数のみが問題にされてきたが, 要素配列規則も含 んで複雑さを議論する必要があろう.

\section{オスはいつさえずるのがトクか？： 繁殖諸活動の中における効果的なさえずり方}

(When do Males Sing Songs?: Costs and Benefits of Singing during a Breeding Cycle. 49: 87-98)

\section{濱尾章二}

浦和市立南高等学校 ₹336-0026 埼玉県浦和市辻6-5-31

鳥のオスが多くの子を残すためには，多くのメスを 受精させることと共に, 子が自立するまでの世話や他 のオスによる受精を排除するための父性防衛が必要に なる. これらの繁殖諸活動のうち, 鳴离類のさえずり は主につがい相手の誘引に使われる手段である.オス が多くのメスを得るためには, 時期を選ばずさえずっ ているべきである. しかし，そのような行動は，ヒナ の餓死やつがい外受精をまねくであろう.

この論文では, 効果的にメスの誘引をはかるために, オスが繁殖諸活動の中でどのように時期を選んでさえ ずっているのかについて検討する，そのために，まず さえずりと他の繁殖活動の間にみられるトレードオフ の関係を示す. 次に, 2 つの鳥種を例にあげて, 繁殖 ステージとさえずり活動の対応を生態的, 社会的条件 と関連づけて論議する. なお，鳥のさえずりには，メ スの誘引の他にもなわばり防衛の機能があるが, これ らの機能は相互に排他的なものではない. 同じ鳴き声 がそれを聞く個体の性によって異なる信号として受け 取られるのである.この論文では，さえずりがメスの 誘引に重要なはたらきをしていると考えられる種を取 り上げ, さえずり活動の変化をメス誘引の観点から考 察する.

スズメ目の種では，父性防衛はメスが受精可能な期 間，常に一緒にいてその行動を追跡するメイトガード によって行われることが多い. Ezaki (1987) は, 特 定のオオヨシキリAcrocephalus arundinaceus のオス を繁殖期を通じて観察し，さえずり活動に費やされた 時間とメスへの連れ添い行動に費やされた時間の間に
負の順位相関があることを見いだした。このことは， さえずることとメイトガードが両立しないことを示唆 している. つがい相手のメスが受精可能な期間にさえ ずって他のメスを誘引することは，オスにとって自ら の父性を失うという出費が生じると考えられる.

日本で繁殖するスズメ目鳥種の中から，子の世話の 雌雄分担について情報があるものについてまとめたと ころ，オスが抱卵を手伝う種は26.6\%であった（Table 1).これらの場合，オスはメスよりも少ししか抱卵し ないことが多いようである，また，全体の $25.3 \%$ の種 では, 抱卵はメスのみによって行われるものの, オス が抱卵中のメスに給慨をする，しかし，その頻度は高 いものではない. これらのことから考えると，多くの 種では抱卵に対するオスの寄与は大きなものではなく, 抱卵がさえずり活動を制限するほどの仕事になってい ないあのと考えられる. 雛への給餉については, オオ ヨシキリで活発にさえずると雊への給餉が少なくなる ことが示されている. 個々のオスについて早朝のさえ ずり頻度と尽間の給餌頻度を同じ日に調べたところ, 両者の間に負の順位相関が認められた (Urano 1990a). 雊への給飭は96.1\%の種では雌雄で行われており (Table 1), この活動がオスのさえずり活動に影響し ている種が多いものと考えられる.

続いて, さえずり活動と繁殖ステージの関係につい て検討する，オオョシキリでは，メスを獲得するとオ スはさえずらなくなるが, メスが産卵を始める頃に再 び独身時と同じくらいの頻度でさえずり始める. オス がこの時期さらなるメスの獲得を目指していることは 